\title{
PENGARUH KEAKTIFAN BERORGANISASI TERHADAP INDEKS PRESTASI KUMULATIF MAHASISWA UNIVERSITAS COKROAMINOTO YOGYAKARTA
}

\author{
Oleh: \\ Heri Kurnia \\ Universitas Cokroaminoto Yogyakarta
}

Penelitian ini bertujuan untuk mengetahui pengaruh keaktifan berorganisasi dan indeks prestasi kumulatif mahasiswa UCY. Penelitian ini merupakan penelitian deskriptif kuantitatif, data yang dikumpulkan berupa data kuantitatif (IPK) dan data kualitatif yang dikuantifikasi (keaktifan berorganisasi), dilakukan di Universitas Cokroaminoto Yogyakarta, sejak Mei sampai bulan Juni 2015. Jumlah sampel dalam penelitian ini adalah 60 dengan teknik snowballing sampling. Data diperoleh dari kuesioner kemudian diolah dengan teknik analisis regresi sederhana dan analisis koefisien determinasi $\left(\mathrm{R}^{2}\right)$. Hasil penelitian menunjukkan: Analisis statistik menghasilkan persamaan regresi $\mathrm{Y}=3,579+-0,018 \mathrm{X}$, artinya jika nilai keaktifan berorganisasi (X) meningkat 1 satuan maka nilai IPK (Y) akan meningkat sebesar $(-0,018)$ satuan dengan nilai konstanta 3,579. Pengujian hipotesis menunjukkan bahwa variabel independen keaktifan berorganisasi terbukti tidak signifikan mempengaruhi variabel dependen IPK. Koefisien determinasi yang diperoleh adalah 0,028 (2,8\%), artinya variabel keaktifan berorganisasi memiliki pengaruh kontribusi sebesar 2,8\% terhadap variabel IPK dan 97,2 \% lainnya dipengaruhi oleh faktor-faktor lain di luar variabel keaktifan berorganisasi yang tidak dianalisis dalam penelitian ini.

Kata Kunci: Keaktifan Organisasi, Prestasi, Mahasiswa UCY

\section{Pendahuluan}

Organisasi adalah suatu kelompok orang dalam suatu wadah untuk tujuan bersama. Dalam ilmu-ilmu sosial, organisasi dipelajari oleh periset dari berbagai bidang ilmu, terutama ilmu politik, manajemen, sosiologi, psikologi, dan ekonomi. Kajian mengenai organisasi sering disebut studi organisasi (organizational studies), perilaku organisasi (organizational behaviour), atau analisa organisasi (organization analysis). Organisasi pada dasarnya digunakan sebagai tempat atau wadah dimana orang-orang berkumpul, bekerjasama secara rasional dan sistematis, terencana, terorganisasi, terpimpin dan terkendali, dalam memanfaatkan sumber daya (uang, material, mesin, metode, lingkungan), sarana prasarana, data, dan lain sebagainya yang digunakan secara efektif dan efisien untuk mencapai tujuan organisasi.

Dengan kata lain, organisasi merupakan suatu persatuan dari berbagai pribadi dengan tujuan dan saling bekerja sama sebagaimana menurut Siagian (2011:12) menyebutkan bahwa 
"Organisasi adalah setiap bentuk persekutuan antara dua orang atau lebih yang bekerja sama dan untuk mencapai tujuan bersama, dan terikat secara formal dalam suatu ikatan hierarki dimana selalu terdapat hubungan antara seorang atau sekelompok orang yang disebut pemimpin dan seorang atau sekelompok orang yang disebut bawahan”. Dengan berorganisasi seorang mahasiswa selain mendapatkan pengalaman sosialisasi tambahan, juga mendapatkan ilmu mengenai tanggung jawab yang sepatutnya dimiliki oleh seorang mahasiswa. Edgar (2000:55) menyatakan "organisasi adalah koordinasi yang direncanakan mengenai kegiatan-kegiatan sejumlah orang untuk mencapai tujuan bersama melalui pembagian kerja dan fungsi berdasarkan tingkatan otoritas (kewenangan) dan tangggung jawab".

Komposisi yang seimbang dari mahasiwa tidak hanya memiliki IQ (Intelligent Quotient) yang tinggi, tetapi juga diimbangi EQ (Emotional Quotient). Berdasarkan banyak penelitian, IQ menentukan sukses seseorang sebesar 20\% sedangkan kecerdasan emosi (EQ) memberi kontribusi $80 \%$. Pembangunan karakter mahasiswa tidak hanya duduk di kelas, menghapal perkataan dosen, dan mengejar nilai (IPK). Ada dinamika lain yaitu kepemimpinan dan proses pendewasaan, lewat organisasi kemahasiswaan kecerdasan emosi terbentuk. Dunia organisasi mengajarkan mahasiswa untuk mampu bersosialisasi, saling membantu, dan bertukar pendapat. Keuntungan lainya mahasiswa siap diterjunkan di tengah masyarakat dan langsung dengan cepat mengaplikasikan ilmunya (Dukarno, 2009:96).

Namun, pada beberapa kenyataan di lapangan terdapat juga beberapa fakta bahwa mahasiswa yang mengikuti organisasi kampus, maka aktifitas perkuliahannya akan terganggu dan bahkan terbengkalai. Mahasiswa aktifis-aktifis organisasi umumnya akan teralihkan perhatian utamanya dengan kegiatan-kegiatan organisasi terutama bagi mahasiswa yang tidak pandai dalam mengatur waktu. Kelompok mahasiswa secara umum dibagi kedalam dua kelompok, yaitu mahasiswa yang apatis dan mahasiswa aktif terhadap organisasi kampus. Mahasiswa yang apatis terhadap organisasi kampus merupakan mahasiswa yang aktif terhadap perkuliahan saja, segala sesuatu diukur dari pencapaian kredit semester dan indeks prestasi kumulatif yang tinggi dan dapat meraih gelar sarjana secepatnya. Sedangkan Mahasiswa aktif adalah Mahasiswa yang aktif dalam berbagai organisasi kemahasiswaan dikampus, yang sering disebut dengan "aktivis kampus". (Trimasanto, 1993:35) 
Pada umumnya sering dijumpai Mahasiswa memiliki kesibukan lain selain kuliah yaitu mengikuti kegiatan organisasi. Karena itu mahasiswa dituntut untuk memiliki kemampuan dalam mengatur waktu belajar maupun dalam mengikuti aktivitas keorganisasian agar mendapatkan prestasi akademik yang optimal. Kegiatan di organisasi kemahasiswaan tersebut merupakan aspek eksternal yang dapat menunjang prestasi akademik mahasiswa, karena pengalaman dan pelajaran tersebut tidak didapatkan dalam bangku perkuliahan (Prastiawan, 2009:15).

Di samping itu, ide dasar tentang pentingnya berorganisasi juga dapat kita jumpai dalam Firman Allah SWT yaitu surah As-Shaff ayat 4 dan Hadis Rasulullah SAW, dimana beliau pernah berpesan "Apabila kita berada pada suatu tempat yang terdiri dari komunitas atau sekelompok orang, maka hendaknya menunjuk salah seorang dari mereka menjadi pemimpin, bahkan meskipun hanya terdiri dari dua orang”. Beliau juga mengumpamakan bahwa "keseluruhan umat Islam adalah bagaikan satu tubuh, bilamana sebagian dari tubuh itu mengalami kesakitan, maka bagian yang lain juga ikut merasakannya”. (H.R. Muslim). Sejalan dengan hadis Nabi tersebut, dalam Al-Qur'an surah As-Shaff ayat 4, Allah SWT berfirman yang artinya: sesungguhnya Allah menyukai orang yang berperang dijalan-Nya dalam barisan yang teratur seakan-akan mereka seperti suatu bangunan yang tersusun kokoh. (Q.S. As-Saff : 4).

Dalam dunia kampus kata "Aktivis" sudah tidak asing lagi terdengar ditelinga bahkan seringkali menjadi topik utama dalam setiap pembicaraan. Selama ini banyak kasus yang sudah melekat pada diri seorang aktivis, mulai dari kegagalan dalam perkuliahan seperti gagal lulus dimata kuliah tertentu dan harus mengulang tahun depan, indeks prestasi rendah atau dibawah rata-rata bahkan hingga keterlambatan didalam kelulusan akademik. Senada dengan pendapat Sudarman: "Seringkali terdengar seorang aktivis, baik pelajar yang aktif di sekolah maupun mahasiswa yang menjadi aktivis di kampus terkadang mengalami penurunan prestasi akademik di tempat belajarnya. Bahkan, untuk mahasiswa yang menjadi aktivis di kampus terkadang mengenyam bangku kuliahnya lebih lama dari masa studi umumnya".

Dan diperkuat lagi dengan pendapat Buhari: "Diantara aktivis di kampus yang belum bisa mensinergikan aktivitas dan akademiknya, jadi tidak jarang seorang aktivis terkesan cuek dengan nilai Kartu Hasil Studinya (KHS) yang rendah atau tidak memuaskan, ataupun dengan teguranteguran dari pihak dosen tentang ketidak disiplinan mereka. Saya tidak menuntut setiap aktivis 
cuek untuk memiliki indeks prestasi yang luar biasa dengan peringkat Cumlaude, tetapi minimal seorang aktivis memiliki indeks prestasi yang bisa dikatakan standar ataupun bagus”.

Mahasiswa merupakan komponen penunjang kemajuan negeri, mahasiswa diharapkan mampu memberikan sumbangan melalui kapasitas intelektualitasnya, sehingga masa kuliah seharusnya dimanfaatkan dengan sebaik-baiknya. Mengikuti aktivitas pada lembaga kemahasiswaan baik tingkat Universitas ataupun tingkat Fakultas dan bahkan pada unit-unit kegiatan mahasiswa (UKM) bukanlah berarti meninggalkan tugas belajar kuliahnya. Menjadi aktivis mahasiswa tidalah berarti menjadikan nilai kuliah menjadi turun, justru menjadi aktivis mahasiswa menjadi ajang pembuktian diri kita bahwa kita adalah mahasiswa yang memiliki nilai lebih dibanding mahasiswa lainnya dan juga sebagai suplemen menggembleng diri.

\section{Kajian Teori}

Pengaruh, Dalam Kamus Besar Bahasa Indonesia (KBBI), menyatakan pengaruh yaitu daya yang ada atau timbul dari sesuatu (orang, benda) yang ikut membentuk watak, kepercayaan, atau perbuatan seseorang. Keaktifan Berorganisasi, dalam Kamus Besar Bahasa Indonesia (KBBI) keaktifan yaitu kegiatan atau kesibukan. Keaktifan berasal dari kata "aktif" yang berarti kegiatan; kesibukan (Sugono, 2008:16). Dengan kata lain ikut sertanya seseorang dalam suatu kegiatan atau organisasi. Sedangkan menurut Nurdiana (2007), keaktifan merupakan suatu perilaku yang dapat dilihat dari keteraturan dan keterlibatan seseorang untuk aktif dalam suatu kegiatan. Ada beberapa aktivitas atau kegiatan yang dilakukan oleh mahasiswa yang aktif berorganisasi (aktivis kampus), antara lain (1) mengikuti rapat, (2) menyelenggarakan seminar, (3) menyelenggarakan kegiatan turnamen olahraga (4) mengikuti kegiatan seni contohnya latihan band, hadroh, bela diri, dan sebagainya. Organisasi Mahasiswa, dalam Kamus Besar Bahasa Indonesia (KBBI) Organisasi merupakan 1 kesatuan (susunan dsb) yg terdiri atas bagian-bagian (orang dsb) dl perkumpulan dsb untuk tujuan tertentu; kelompok kerja sama antara orang-orang yg diadakan untuk mencapai tujuan bersama.

James D. Mooney mendefinisikan organisasi sebagai berikut: "Organization the form of everyhuman, association for the assignment of common purpose" atau organisasi adalah bentuk setiap perserikatan manusia untuk mencapai tujuan bersama. Pengertian organisasi adalah kolektivitas orang-orang yang bekerja sama secara sadar dan sengaja untuk mencapai tujuan 
tertentu Thoha, (2007:10). Organisasi adalah suatu unit yang terkoordinasi yang terdiri atas setidaknya 2 orang yang berfungsi untuk mencapai tujuan umum. Menurut Sondang P. Siagian (2012:24), Organisasi adalah setiap bentuk persekutuan antara dua orang atau lebih yang bekerja bersama serta secara formal terikat dalam rangka pencapaian suatu tujuan yang telah ditentukan dalam ikatan yang mana terdapat seseorang/ beberapa orang yang disebut atasan dan seorang/ sekelompok orang yang disebut dengan bawahan".

Chester Irving Barnard (1999:62) berpendapat bahwa “Define orgazation as a system of cooperative of two or more persons" organisasi adalah merupakan suatu sistem aktivitas kerja sama yang dilakukan oleh dua orang atau lebih. Menurut Malayu S. P. Hasibuan (2012:32) mengatakan "organisasi ialah suatu sistem perserikatan formal, berstruktur dan terkoordinasi dari sekelompok yang bekerja sama dalam mencapai tujuan tertentu. Organisasi hanya merupakan alat dan wadah saja". Menurut Edgar H. Shein (1982:32) dalam bukunya Psychology of Organization, memberikan definisi yaitu; "An organization is the plan coordination of the activities of a member os people for the achievement of some common explicit purpose or good, through division of labor and function and through a hierarchy of authority and responsibility." Jadi organisasi adalah koordinasi yang direncanakan mengenai kegiatan-kegiatan sejumlah orang untuk mencapai tujuan bersama melalui pembagian kerja dan fungsi berdasarkan tingkatan otoritas (kewenangan) dan tangggung jawab. Elemen-elemen yang terkandung dari definisi di atas adalah:

1) Bahwa organisasi menuntut pengembangan dan pemeliharaan koordinasi.

2) Bahwa di dalam organisasi terdapat tujuan bersama yang pencapaiannya harus diupayakan semaksimal mungkin.

3) Dalam organisasi terdapat pembagian kerja (division of labor).

4) Seluruh kegiatan dalam organisasi harus menciptakan keterpaduan (integration), menekankan bahwa objek koordinasi pada dasarnya bukan orang tetapi kegiatan atau pekerjaan.

Sebuah organisasi dapat terbentuk karena dipengaruhi oleh beberapa aspek seperti penyatuan visi dan misi serta tujuan yang sama dengan perwujudan eksistensi sekelompok orang tersebut terhadap masyarakat. Organisasi yang dianggap baik adalah organisasi yang dapat diakui keberadaannya oleh masyarakat disekitarnya, karena memberikan kontribusi. Organisasi 
kemahasiswaan merupakan bentuk kegiatan di perguruan tinggi yang diselenggarakan dengan prinsip dari, oleh dan untuk mahasiswa (Silvia Sukirman, 2004:72). Organisasi tersebut merupakan wahana dan sarana pengembangan diri mahasiswa ke arah perluasan wawasan peningkatan ilmu dan pengetahuan, serta integritas kepribadian mahasiswa. Organisasi kemahasiswaan juga sebagai wadah pengembangan kegiatan ekstrakurikuler mahasiswa diperguruan tinggi yang meliputi pengembangan penalaran, keilmuan, minat, bakat dan kegemaran mahasiswa itu sendiri (Paryati Sudarman, 2004:34-35). Hal ini dikuatkan oleh Kepmendikbud RI. No. 155/U/1998 Tentang Pedoman Umum Organisasi Kemahasiswaan di Perguruan Tinggi, bahwa Organisasi kemahasiswaan intra-perguruan tinggi adalah wahana dan sarana pengembangan diri mahasiswa ke arah perluasan wawasan dan peningkatan kecendikiaan serta integritas kepribadian untuk mencapai tujuan pendidikan tinggi. Sedangkan menurut Silvia Sukirman (2004:69), "Organisasi kemahasiswaan adalah kegiatan tidak wajib atau pilihan yang penting diikuti oleh setiap Mahasiswa selama studinya sehingga melengkapi hasil belajar secara utuh. Pilihan Kegiatan ekstrakurikuler harus sesuai dengan minat dan bakat Mahasiswa karena kegiatan tersebut merupakan sarana pelengkap pembinaan kemampuan pribadi sebagai calon intelektual di masyarakat nantinya". Dari uraian di atas maka dapat disimpulkan bahwa kegiatan organisasi kemahasiswaan meliputi pengembangan penalaran, keilmuan, minat, bakat dan kegemaran yang bisa diikuti oleh mahasiswa di tingkat jurusan, fakultas dan universitas. Tujuannya untuk memperluas wawasan, ilmu dan pengetahuan serta membentuk kepribadian mahasiswa.

Dari beberapa definisi di atas dapat disimpulkan bahwa organisasi adalah suatu sistem formal yang terdiri dari pola aktivitas yang dilakukan sekelompok orang (dua atau lebih) yang bersama secara teratur dan berulang-ulang untuk mencapai tujuan bersama. Organisasi kampus sering dikaitkan keberadaannya dengan aktivis, dan sebaliknya aktivis pasti terkait organisasi kampus. Menurut Kamus Besar Bahasa Indonesia (Balai Pustaka, 2002), aktivis adalah individu atau sekelompok orang (terutama anggota politik, sosial, buruh, petani, pemuda, mahasiswa, perempuan) yang bekerja aktif mendorong pelaksanaan sesuatu atau berbagai kegiatan di organisasinya. Aktivis adalah orang yang tidak tenang (gelisah) ketika terjadi ketidak adilan di lingkungannya dengan cara melakukan perubahan tertentu mulai dari titik nol sampai tujuannya tersebut tercapai. Seorang aktivis, selain aktif di organisasi tertentu (sebagai organisatoris), dia 
juga mempunyai pekerjaan lain di luar itu yaitu memperjuangkan hak-hak orang lain. Dari beberapa pendapat di atas dapat ditarik kesimpulan bahwa aktivis merupakan orang yang gelisah melihat ketidakadilannya, bergerak melakukan perubahan untuk mencapai tujuannya yang biasanya bersifat sosial. Jadi, aktif organisasi adalah ikut secara aktif dalam melakukan perubahan karena adanya ketidakadilan di lingkungan dan merupakan suatu sistem formal yang di dalamnya terdapat sekelompok orang yang bekerja bersama untuk mencapai tujuan bersama.

Indeks Prestasi, indeks Prestasi adalah nilai kredit rata-rata yang merupakan satuan nilai akhir yang menggambarkan mutu penyelesaian satu program studi. Indeks Prestasi dihitung, baik pada setiap akhir semester dengan hasil yang disebut IP semester, maupun pada akhir program pendidikan lengkap satu jenjang, dengan hasil yang disebut IP lengkap atau kumulatif (IPK) Indeks Prestasi Semester (IP Semester) atau Indeks Prestasi Kumulatif/ kolektif (IPK), tidak terlepas dari peran mahasiswa dalam melakukan proses belajar, baik dalam pelaksanaan perkuliahan (kehadiran), atau dalam menyelesaikan tugas dosen, atau bahkan dalam menjawab soal-soal ketika Ujian Tengah Semester/ Mid Semester (UTS) terlebih lagi ketika Ujian Akhir Semester. Ada beberapa hal yang berkaitan erat dengan Indeks Prestasi (prestasi belajar), anatar lain:

\section{a. Pengertian Prestasi Belajar}

Prestasi belajar adalah sebuah kalimat yang terdiri dari dua kata, yakni prestasi dan belajar. Untuk memahami lebih jauh tentang pengertian prestasi belajar, penulis menjabarkan makna dari kedua kata tersebut.

Menurut Kamus Umum Bahasa Indonesia, pengertian prestasi adalah hasil yang telah dicapai (dari yang telah diakukan, dikerjakan, dan sebagainya) (1991: 787). Sedangkan menurut Saiful Bahri Djamarah (1994:20-21) dalam bukunya Prestasi Belajar dan Kompetensi Guru, bahwa prestasi adalah apa yang telah dapat diciptakan, hasil pekerjaan, hasil yang menyenangkan hati yang diperoleh dengan jalan keuletan kerja. Dalam buku yang sama Nasrun Harahap, berpendapat bahwa prestasi adalah penilaian pendidikan tentang perkembangan dan kemajuan siswa berkenaan dengan penguasaan bahan pelajaran yang disajikan kepada siswa. Seirama dengan pendapat di atas, Fudyartanto menyatakan, "Prestasi adalah taraf kemampuan anak untuk menguasai sejumlah pengetahuan dan ketrampilan yang ada pada seseorang yang berbeda". (dalam Diyanto, 2004: 21). Menurut W. J. S. Poerwodarminto menyatakan, "Prestasi 
belajar adalah hasil yang dicapai setelah seseorang melakukan kegiatan belajar". (dalam Diyanto, 2004: 21). Prestasi juga merupakan suatu hasil yang dicapai atau pengukuran kemampuan seseorang dalam penguasaan pengetahuan dan keterampilan.

Dari pengertian di atas, dapat diambil kesimpulan bahwa prestasi adalah hasil dari suatu kegiatan seseorang atau kelompok yang telah dikerjakan, diciptakan dan menyenangkan hati yang diperoleh dengan jalan bekerja. Selanjutnya untuk memahami pengertian tentang belajar berikut dikemukakan beberapa pengertian belajar diantaranya menurut Slameto (2003:2) dalam bukunya Belajar dan faktor-faktor yang mempengaruhinya bahwa belajar ialah suatu usaha yang dilakukan seseorang untuk memperoleh suatu perubahan tingkah laku yang baru secara keseluruhan, sebagai hasil pengalamannya sendiri dalam interaksi dengan lingkungannya. Pengertian belajar menurut Morgan dalam bukunya The conditions if Learning, "Belajar adalah setiap perubahan yang relativ menetap dalam tingkah laku yang terjadi sebagai suatu hasil dari latihan atau pengalaman". (dalam Suparno, 2006: 11). Gagne dalam bukunya The Conditions of Learning 1977, mengatakan belajar merupakan sejenis perubahan yang diperlihatkan dalam perubahan tingkah laku, yang keadaaannya berbeda dari sebelum individu berada dalam situasi belajar dan sesudah melakukan tindakan yang serupa itu. Perubahan terjadi akibat adanya suatu pengalaman atau latihan. Berbeda dengan perubahan serta-merta akibat refleks atau perilaku yang bersifat naluriah.

Menurut Muhibbin Syah (2000:136) bahwa belajar adalah tahapan perubahan seluruh tingkah laku individu yang relativ menetap sebagai hasil pengalaman dan interaksi dengan lingkungan yang melibatkan proses kognitif. Begitu juga menurut James Whitaker yang dikutip oleh Wasty Soemanto (1990: 98-99), belajar adalah proses dimana tingkah laku ditimbulkan atau diubah melalui latihan dan pengalaman. Berdasarkan beberapa pendapat di atas, bahwa belajar merupakan kegiatan yang dilakukan secara sadar dan rutin pada seseorang sehingga akan mengalami perubahan secara individu baik pengetahuan, keterampilan, sikap dan tingkah laku yang dihasilkan dari proses latihan dan pengalaman individu itu sendiri dalam berinteraksi dengan lingkungannya. Dalam dunia pendidikan, prestasi dan belajar mempunyai hubungan yang sangat erat sehingga sulit dipisahkan. Prestasi dapat menunjukkan seberapa jauh nilai yang diperoleh dalam setiap kegiatan atau belajar. Dari suatu nilai kemampuan yang menunjukkan hasil yang tertinggi dicapai dalam suatu saat yang tertentu itulah disebut prestasi. Menurut 
Winkel melalui Sunarto (1996:162) mengatakan bahwa "prestasi belajar adalah suatu bukti keberhasilan belajar atau kemampuan seorang siswa dalam melakukan kegiatan belajarnya sesuai dengan bobot yang dicapainya".

Menurut Abu Ahmadi dan Widodo Supriyono (1990:130) prestasi belajar merupakan hasil interaksi antara berbagai faktor yang mempengaruhinya baik dari dalam diri (faktor internal) maupun dari luar (faktor eksternal) individu. Berdasarkan beberapa batasan diatas, prestasi belajar dapat diartikan sebagai kecakapan nyata yang dapat diukur yang berupa pengetahuan, sikap dan keterampilan sebagai interaksi aktif antara subyek belajar dengan obyek belajar selama berlangsungnya proses belajar mengajar untuk mencapai hasil belajar.

\section{b. Penilaian di Perguruan Tinggi}

Pelaksanaan akademik di perguruan tinggi dalam pelaksanaannya terdapat perbedaan antara administrasi dasar dan menengah. Perbedaan itu dapat dilihat dari mata pelajaran dan jadwal kegiatan. Jika dilihat dari Sekolah Dasar (SD) dan Menengah dapat mengalami persamaan dalam mata pelajaran di angkatan yang sama, sedangkan di Perguruan Tinggi (PT) untuk mata pelajaran setiap angkatan saja bisa berbeda. Hal ini disebabkan karena dalam Perguruan Tinggi menggunakan Sistem Kredit Semester (SKS). Sistem Kredit Semester merupakan suatu sistem penyelenggaraan pendidikan dimana beban studi Mahasiswa, beban kerja tenaga pengajar dan beban penyelenggara lembaga pendidikan dinyatakan dalam satuan kredit semester. Jadi, satuan kecil sebagai satuan program pendidikan yang dipergunakan sebagai dasar administrasi akademik adalah semester. SKS sangat membantu dalam usaha menyelesaikan studi dengan hasil yang maksimal. Pengambilan SKS di perguruan tinggi dapat disesuaikan agar tidak mengganggu kegiatan perkuliahan sehingga memperoleh hasil yang maksimal tanpa ada tekanan. Sistem penilaian hasil studi di Perguruan Tinggi tidak lagi menggunakan sistem penilaian dari angka 0 sampai dengan 100. Penilaian hasil belajar untuk setiap mata kuliah dinyatakan dengan huruf A, B, C, D dan E yang masing-masing berbobot 4, 3, 2, 1 dan 0 . 
Tabel 1

Bobot penilaian berdasarkan nilai

\begin{tabular}{|c|c|c|}
\hline Nilai & Angka/ bobot & Arti \\
\hline A & 4 & Sangat baik \\
\hline B & 3 & Baik \\
\hline C & 2 & Cukup \\
\hline D & 1 & Kurang \\
\hline E & 0 & Gagal \\
\hline
\end{tabular}

Mahasiswa, Mahasiswa adalah "MAHA" dan "SISWA", yaitu seorang siswa yang telah mencapai tingkat lebih tinggi lagi. Mahasiswa adalah seseorang yang sedang menuntut ilmu di perguruan tinggi. Mahasiswa adalah seseorang yang memiliki potensial dalam memahami perubahan dan perkembangan di dunia pendidikan dan lingkungan masyarakat. Yang memiliki posisi dan peran sebagai agent of change, social controler, dan the future leader. Mahasiswa sebagai bagian dari kaum muda dalam tatanan masyarakat yang mau tidak mau pasti terlibat langsung dalam tiap fenomena sosial, harus mampu mengimplementasikan kemampuan keilmuannya dalam akselerasi perubahan keumatan ke arah berkeadaban. Dalam peraturan pemerintah RI No.30 tahun 1990 adalah peserta didik yang terdaftar dan belajar di perguruan tinggi tertentu. Selanjutnya menurut Sarwono (1998:85), "mahasiswa adalah setiap orang yang secara resmi terdaftar untuk mengikuti pelajaran di perguruan tinggi dengan batas usia sekitar 18-30 tahun".

Mahasiswa merupakan suatu kelompok dalam masyarakat yang memperoleh statusnya karena ikatan dengan perguruan tinggi. Mahasiswa juga merupakan calon intelektual atau cendekiawan muda dalam suatu lapisan masyarakat. Sedangkan pengertian Mahasiswa menurut Knopfemacher (dalam Suwono, 1978:35) adalah "merupakan insan-insan calon sarjana yang dalam keterlibatannya dengan perguruan tinggi (yang makin menyatu dengan masyarakat), dididik dan di harapkan menjadi calon-calon intelektual".

\section{Pembahasan}

Menjadi aktivis kampus adalah sebuah panggilan jiwa, menjadi aktivis kampus juga sering dikatakan memiliki IPK yang rendah dan bahkan dibawah rata-rata. Peneliti tertarik untuk meneliti hal tersebut diatas, penelitian ini di lakukan di Universitas Cokroaminoto Yogyakarta 
dari pertengahan bulan Mei 2015 sampai akhir bulan Juni 2015. Sampel penelitian ini sebanyak 60 responden, diambil dengan metode snowballing sampling pada aktivis kampus angkatan 2011-2014. Dalam penelitian ini pengaruh keaktifan berorganisasi variabel X dan Indeks Prestasi Kumulatif sebagai variabel Y.

Analisis data dalam penelitian ini menggunakan teknik analisis regresi sederhana serta analisis koefisien determinasi $\left(\mathrm{R}^{2}\right)$. Hasil analisis data adalah sebagai berikut:

\section{Analisis data model coefficients}

Berdasrkan Tabel 24 (output data model coefficients), menginformasikan model persamaan regresi yang diperoleh dengan koefisien konstanta dan koefisien variabel yang ada di kolom Unstandardized Coefficients B. Berdasarkan output data pada Tabel 24, kolom B pada Constant $(\alpha)$ adalah 3,579 sedangkan skor keaktifan berorganisasi (X) -0,018. Sehingga persamaan regresinya adalah adalah: $\mathrm{Y}=\alpha+\mathrm{bX}$ atau $\mathrm{Y}=3,579+-0,018$. Persamaan tersebut menunjukkan bahwa Skor koefisien X sebesar -0,18 yang berarti apabila skor keaktifan berorganisasi (X) meningkat 1 satuan maka Skor Indeks Prestasi Kumulatif (Y) akan meningkat sebesar (-0,018) satuan dengan skor konstanta 3,579.

\section{Analisis data Model Summary}

Berdasarkan output data model summary (Tabel 25) menampilkan skor R yang merupakan simbol dari skor koefisien korelasi dari Pearson. Pada data model summary ini skor korelasi adalah 0,166. Skor ini dapat diinterpretasikan bahwa hubungan kedua variabel penelitian ada di kategori cukup kuat. Melalui model summary ini juga diperoleh skorR Square $\left(\mathrm{R}^{2}\right)$ atau koefisien determinasi (KD) yang menunjukkan seberapa bagus model regresi yang dibentuk oleh interaksi variabel bebas dan variabel terikat. Skor KD yang diperoleh adalah 0,028 atau sebesar 2,8\% yang dapat ditafsirkan bahwa variabel bebas keaktifan berorganisasi memiliki pengaruh kontribusi sebesar 2,8\% terhadap variabel Indeks Prestasi Kumulatif dan 97,2\% lainnya dipengaruhi oleh faktor-faktor lain diluar variabel keaktifan berorganisasi yang tidak dianalisis dalam penelitian ini. 


\section{Uji Hipotesis}

Pengujian hipotesis dalam penelitian ini menggunakan uji statistik t. Ketentuan hasil uji t ialah:

- $\quad \mathrm{H}_{0}$ : Tidak ada pengaruh yang nyata (signifikan) variabel keaktifan berorganisasi (X) terhadap IPK (Y)

- $\quad \mathrm{H}_{1}$ : Ada pengaruh yang nyata (signifikan) variabel Keaktifan Berorganisasi (X) terhadap Variabel IPK (Y)

\section{Catatan:}

Apabla nilai signifikansi <0,05. maka $\mathrm{H} 0$ ditolak dan $\mathrm{H} 1$ diterima.

Hasil uji statistik t dengan menggunakan bantuan program SPSS 22, adalah sebagai berikut:

\section{Tabel}

\section{Hasil Pengujian Hipotesis}

\begin{tabular}{|c|c|c|c|c|c|c|c|c|c|c|}
\hline \multicolumn{11}{|c|}{ Coefficients $^{\mathrm{a}}$} \\
\hline \multirow[b]{2}{*}{ Model } & \multicolumn{2}{|c|}{$\begin{array}{l}\text { Unstandardized } \\
\text { Coefficients }\end{array}$} & \multirow{2}{*}{\begin{tabular}{|c|}
$\begin{array}{c}\text { Standardiz } \\
\text { ed } \\
\text { Coefficients }\end{array}$ \\
Beta \\
\end{tabular}} & \multirow[b]{2}{*}{$\mathrm{T}$} & \multirow[b]{2}{*}{ Sig. } & \multicolumn{3}{|c|}{ Correlations } & \multicolumn{2}{|c|}{ Collinearity Statistics } \\
\hline & B & $\begin{array}{l}\text { Std. } \\
\text { Error }\end{array}$ & & & & $\begin{array}{l}\text { Zero- } \\
\text { order }\end{array}$ & Partial & Part & $\begin{array}{c}\text { Toleran } \\
\text { ce }\end{array}$ & VIF \\
\hline 1 (Constant) & 3,579 & ,125 & & 28,693 &, 000 & & & & & \\
\hline$x$ &,- 018 & ,014 &,- 166 & $-1,282$ & ,205 &,- 166 &,- 166 &,- 166 & 1,000 & 1,000 \\
\hline
\end{tabular}

a. Dependent Variable: $\mathrm{Y}$

Sumber: hasil olah data menggunakan SPSS Statistics 22

Pengujian terhadap hipotesis ini dilakukan melalui pengujian signifikansi koefisien regresi dari variabel $\mathrm{X}$. Hipotesis keaktifan berorganisasi (variabel $\mathrm{X}$ ) yang berpengaruh terhadap IPK. Diperoleh nilai $t_{\text {hitung }}=-1,282$ dengan nilai signifikansi 0,205>0,05, maka $\mathrm{H}_{0}$ diterima dan $\mathrm{H}_{1}$ ditolak, sehingga hipotesis penelitian ini ditolak. Dengan demikian, maka mahasiswa yang aktif berorganisasi akan menurunkan Indeks Prestasi Kumulatif (IPK) walaupun tidak signifikan.

\section{Kesimpulan}

Dari hasil uji hipotesis menunjukkan bahwa terdapat pengaruh yang tidak signifikan keaktifan berorganisasi terhadap Indeks Prestasi Kumulatif Mahasiswa Universitas Cokroaminoto Yogyakarta angkatan 2011-2014. Hasil analisis regresi yang menunjukkan persamaan $\mathrm{Y}=3,579+-0,018 \mathrm{X}$. Persamaan ini artinya bahwa nilai koefisien $\mathrm{X}$ sebesar $-0,018$ 
yang berarti apabila nilai keaktifan berorganisasi (X) meningkat 1 satuan maka nilai Indeks Prestasi Kumulatif (Y) akan meningkat sebesar $(-0,018)$ satuan dengan nilai konstanta 3,579. Selain itu, diketahui juga koefisien determinasi $\mathrm{r}^{2}$ (R Square) sebesar 0,028. Nilai tersebut berarti 2,8 \% perubahan pada variabel Indeks Prestasi Kumulatif (Y) dapat diterangkan oleh variabel keaktifan berorganisasi (X) sedangkan 97,2\% lainnya dipengaruhi oleh faktor-faktor lain diluar variabel keaktifan berorganisasi yang tidak dianalisis dalam penelitian ini. Faktor utama yang mempengaruhi keaktifan berorganisasi terhadap indeks prestasi kumulatif adalah pada kualitas aktivis itu sendiri mulai dari kefahaman mereka dalam berorganisasi, niat ikut berorganisasi, motivasi dan tata cara para aktivis yang bersangkutan dalam membagi waktu dengan perkuliahan supaya memiliki dua predikat, yaitu berpredikat menjadi aktivis kampus dan sekaligus lulus dengan berpredikat cumlaude.

\section{Daftar Pustaka}

Tim Penyusun Kamus Pusat Bahasa, 2001. Kamus Besar Bahasa Indonesia Edisi ketiga. Jakarta: Balai Pustaka.

Departemen Agama RI, 2007. Al-Qur'an dan Terjemahnya. Surakarta: Media Insani Publishing.

Nawawi, Hadari, 2000. Metode Penelitian Bidang Sosial. Yogyakarta: Gadjah Mada University Pers.

Hadi, Sutrisno, 1993. Metodoligi Research 2. Yogyakarta: Andi Offset.

Surahmad, Winarto, 1992. Pengantar Penelitian Ilmiah Dasar Metode dan Teknik. Bandung: Tarsito.

Sudjiono, Anas, 1986. Teknik Evaluasi Pendidikan Suatu Pengantar. Yogyakarta: U. D. Rama.

Arikunto, Suharsimi, 2002. Penelitian Suatu Pendekatan Praktik Edisi Revisi V. Jakarta: PT. Rineka Cipta.

Moleong, Lexi J, 2004. Metodologi Penelitian Kualitatif. Bandung: Remaja Rosda Karya.

Sugiono, 2010. Metodologi Penelitian Pendidikan: Pendekatan Kuantitatif, Kualitatif, dan $R$ \& $D$. Bandung: Alfabeta.

Emzir, 2010. Metodologi Penelitian Kualitatif Analisis data. Jakarta: Rajawali Press.

Azwar, Saifuddin 2007. Metode Penelitian. Yogyakarta: Pustaka Pelajar. 